\title{
Complement activation as a mediator of antiphospholipid antibody induced pregnancy loss and thrombosis
}

\author{
J E Salmon, G Girardi, V M Holers
}

Ann Rheum Dis 2002;61(Suppl II):ii46-ii50

$\mathrm{T}$ he antiphospholipid antibody syndrome (APS) is characterised by increased risk of vascular thrombosis involving venous, arterial, and placental circulations. The last of these is associated with poor obstetrical outcomes, including fetal death and growth retardation. Pregnancy loss is a defining criterion for APS and occurs with particularly high frequency in systemic lupus erythematosus (SLE) patients bearing this antibody. Patients meet the criteria for APS if they have three otherwise unexplained embryonic losses (before 10 weeks gestation) or one otherwise unexplained fetal loss after 10 weeks, with or without placental infarction or fetal growth restriction. ${ }^{1-3}$

Over the past two decades, APS has emerged as a leading cause of pregnancy loss and pregnancy related morbidity. It is now recognised that recurrent miscarriage occurs in $1 \%$ of couples, $^{4-7}$ that up to $20 \%$ of women with recurrent miscarriage have antiphospholipid (aPL) antibodies, and that in about $15 \%$ of otherwise apparently normal women aPL is the sole explanation for recurrent fetal loss. ${ }^{89}$ The primary treatment for these patients, anticoagulation throughout pregnancy, is inconvenient, sometimes painful, expensive, and fraught with potential complications, including haemorrhage and osteoporosis. Moreover, it is often ineffective. Thus, the identification of a novel mechanism for pregnancy loss in women with aPL antibodies holds the promise of new, safer, and better treatments.

Awareness of the association of aPL antibodies with pregnancy complications has increased the frequency with which APS is diagnosed and generated substantial interest in elucidating its pathophysiology. At present, though the association of aPL antibodies with pregnancy loss and pregnancy morbidity is secure, its mechanism remains unknown. ${ }^{10}$ Defining this mechanism is crucial for several reasons. Firstly, there is considerable variability in the success rates of the various treatments, "1 suggesting that different but still undefined treatments may be optimal in specific subsets of women with aPL. Secondly, current treatment regimens are imperfect and many treated pregnant patients suffer complications such as pre-eclampsia, uteroplacental insufficiency, intrauterine fetal growth restriction, and preterm birth. ${ }^{11}{ }^{12}$ Thirdly, understanding how aPL antibodies "cause" miscarriage will probably lead to important insights into the mechanisms of miscarriages in general, thereby benefiting women with non-aPL related miscarriages.

\section{ANTIPHOSPHOSPHOLIPID ANTIBODIES INDUCE TISSUE DAMAGE}

Although it is clear that the specific antigenic reactivity of aPL antibodies is critical to their effect, the pathogenic mechanisms that result in injury in vivo are incompletely understood. To elucidate these mechanisms, several murine models have been developed. In one particularly informative model, passive transfer of human IgG isolated from aPL antibody positive sera, or of murine and human monoclonal aPL antibodies, into pregnant mice induces fetal loss and growth retardation, demonstrating the direct pathogenic role of aPL antibodies. ${ }^{13-17}$ Recent in vitro studies in human placentas have shown that trophoblast cell membranes attract both phospholipid binding protein $\beta 2$-glycoprotein I ( $\beta 2$ GPI) dependent and $\beta 2$ GPI independent aPL antibodies, ${ }^{18}$ suggesting a mechanism by which these antibodies specifically target the placenta.

Despite appreciation of the importance of antigens recognised by aPL antibodies, it has not been shown that the ability of aPL antibodies to change target antigen functions is in itself sufficient for such highly deleterious in vivo outcomes as recurrent fetal loss. In addition, while experimental models have emphasised the role of thrombosis in placental tissue, histopathological findings in placentas from women with APS argue that proinflammatory factors may contribute to injury. ${ }^{15}{ }^{18-20}$ In vivo and in vitro studies have demonstrated that aPL antibodies trigger activation of endothelial cells, monocytes, and platelets, which are also capable of causing tissue damage. ${ }^{21-23}$

We hypothesised that complement activation is a necessary in vivo intermediary step critical for the full pathogenic effect of aPL antibodies on platelets and endothelial or trophoblast cells within the placenta and at other sites where aPL antibodies are deposited. We considered this mechanism because it is well established that activated complement fragments themselves have the capacity to bind and activate inflammatory and endothelial cells as well as induce a prothrombotic phenotype, either directly through MAC or through receptor mediated effects (reviewed in Holers ${ }^{24}$ ). These in vivo pathogenic effects require both recognition of relevant target antigens by aPL antibodies and Fc domain mediated recruitment of complement activating effector functions. The validity of this novel hypothesis has been confirmed in our recently published studies that show that complement activation is required for the induction of fetal loss in vivo by aPL antibodies and consequently, that complement activation is a critical proximal effector mechanism in aPL antibody induced fetal injury. ${ }^{25}$

\section{COMPLEMENT ACTIVATION AND TISSUE INJURY}

The complement system, comprised of over 30 proteins that act in concert to protect the host against invading organisms, starts the inflammatory response and tissue injury. ${ }^{26}{ }^{27}$ The classic and alternative pathways of the complement system are activated by mechanisms relevant to the immunopathogenesis of vascular injury in SLE. The classic pathway is activated when natural or elicited antibodies bind to antigen and unleash effectors associated with humoral responses in immune mediated tissue damage. Alternative pathway activation mechanisms differ in that they are initiated by the binding of spontaneously activated complement components to

Abbreviations: aPL, antiphospholipid; APS, antiphospholipid antibody syndrome; SLE, systemic lupus erythematosus 


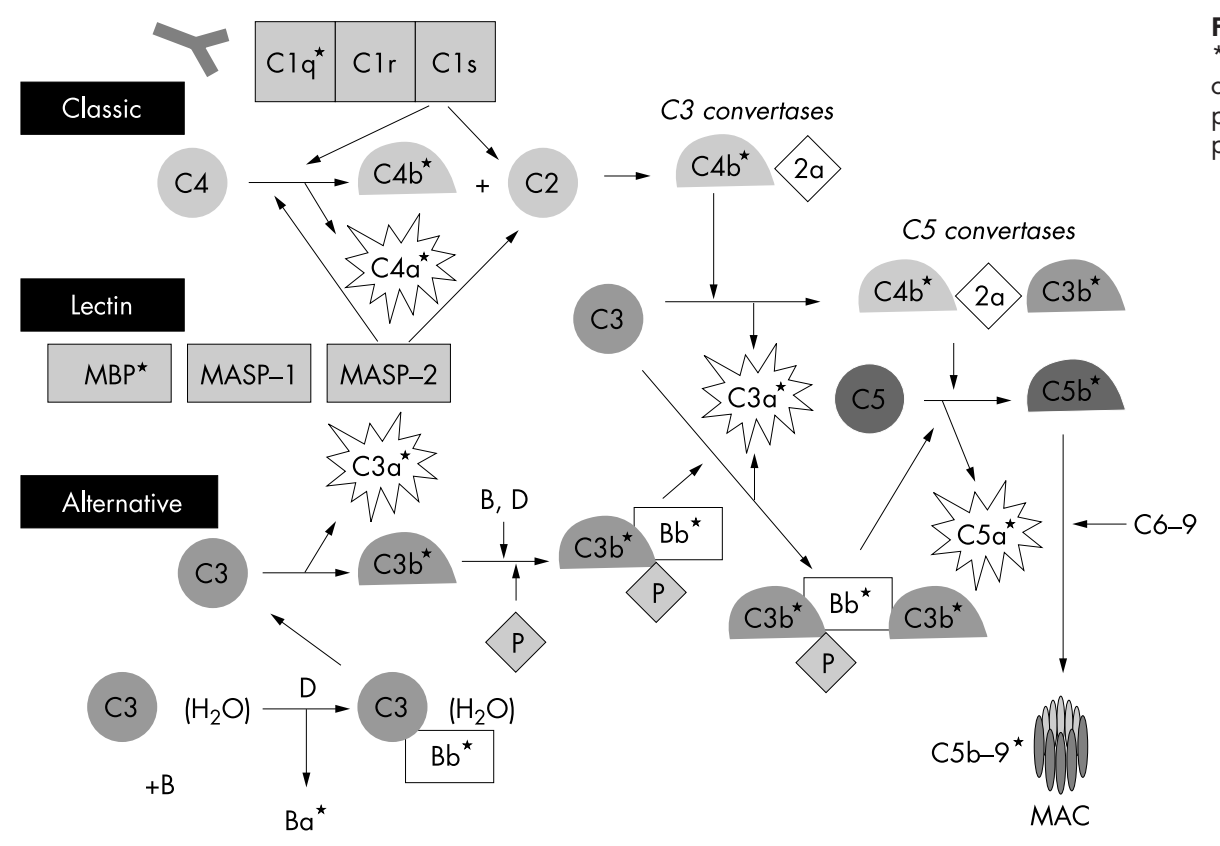

Figure 1 The complement cascade. *Indicates known biologically active complement fragments with the potential to influence the pathophysiology of disease.

the surface of pathogens and other targets such as self tissues. By means of these recognition and activation mechanisms, as well as the lectin pathway of activation, the complement system identifies and responds to "dangerous" situations presented by foreign antigens, pathogens, tissue injury, ischaemia, apoptosis, and necrosis. ${ }^{28}$ This capacity places the complement system at the centre of many clinically important responses to foreign pathogens and to fetal injury mediated by cellular or humoral immune mechanisms.

Three complement activation pathways converge on the $\mathrm{C} 3$ protein, a nexus to effector functions, which is then cleaved to generate fragments $\mathrm{C} 3 \mathrm{a}$ and $\mathrm{C} 3 \mathrm{~b}$ (fig 1). C3a is an anaphylatoxin that binds to receptors on leucocytes and other cells, resulting in the activation and release of soluble inflammatory mediators. ${ }^{29} \mathrm{C} 3 \mathrm{~b}$ and its further sequential cleavage fragments, iC3b and $\mathrm{C} 3 \mathrm{~d}$, are ligands for complement receptors 1 and 2 (CR1 and CR2) and for the $\beta 2$ integrins, $\mathrm{CD} 1 \mathrm{lb} / \mathrm{CD} 18$ and CDIlc/CD18, which are present on a variety of inflammatory and immune accessory cells. ${ }^{24}{ }^{30} \mathrm{C} 3 \mathrm{~b}$ attaches covalently to targets, followed by assembly of C 5 convertase and the subsequent cleavage of $\mathrm{C} 5$ to $\mathrm{C} 5 \mathrm{a}$ and $\mathrm{C} 5 \mathrm{~b}$. C5a is a potent soluble inflammatory anaphylatoxic and chemotactic molecule that promotes recruitment and activation of neutrophils (PMN) and monocytes and mediates endothelial cell activation through its receptor (C5aR, CD88), a member of the heptahelical seven transmembrane spanning protein family. ${ }^{31}$ On endothelial cells, C5a binding results in increased expression of $\mathrm{P}$ selectin and markedly increases neutrophil adhesion. ${ }^{33} \mathrm{C} 5 \mathrm{aR}$ has also been described on vascular smooth muscle cells, renal mesangial cells, and bronchial and alveolar cells. Binding of $\mathrm{C} 5 \mathrm{~b}$ to the target initiates the non-enzymatic assembly of the C5b-9 MAC. Insertion of C5b-9 MAC can result in erythrocyte lysis. However, the important effect of C5b-9 MAC in disease is on nucleated cells where it activates proinflammatory signalling pathways through the interaction of membrane associated MAC proteins with heterotrimeric G proteins. ${ }^{3435}$

In contrast with the somewhat uncertain role of $\mathrm{C} 3$ and the more proximal complement components, such as Clq, SAP or $\mathrm{C} 4$, in promoting or protecting from lupus-like autoimmune disease, it is well accepted that activation of C5 and the insertion of MAC in the cell membrane results in a profound proinflammatory state without the likelihood of changes in self tolerance ${ }^{36}$ For this reason, therapeutic strategies that target C5 and the more distal complement components but leave $\mathrm{C} 3$ and the more proximal components unaffected are now considered an especially promising approach to complement inhibition.

\section{ROLE OF COMPLEMENT IN FETAL TOLERANCE}

As fetal tissues are semi-allogeneic and alloantibodies commonly develop in the mother, the placenta is potentially subject to complement mediated immune attack at the maternal-fetal interface. ${ }^{37}$ Though activated complement components are present in normal placentas ${ }^{38}{ }^{39}$ in successful pregnancy it seems that uncontrolled complement activation is prevented by three regulatory proteins present on the trophoblast membrane. ${ }^{40} 41$ Several studies have shown that the level of activated complement components present at a given site depends on the relative effects of complement activators and its inhibitors: DAF, MCP, and CD59. ${ }^{42}$ All three proteins are expressed on the trophoblast in contact with maternal blood and tissues, providing a mechanism to protect the fetus from damage due to complement pathway activation by alloantibodies. Indeed, on the basis of their characteristic distribution patterns, it is likely that these proteins are strategically positioned for this purpose.

Recent murine studies have underscored the importance of complement regulation in fetal control of maternal processes that mediate tissue damage. In mice, Crry is a membrane bound intrinsic complement regulatory protein whose role, like that of DAF and MCP, is to block C3 and C4 activation on self membranes. ${ }^{43}$ As such, Crry acts as an inhibitor of classic and alternative pathway C3 convertases and blocks C3, C5, and subsequent MAC activation. That appropriate complement inhibition is an absolute requirement for normal pregnancy has been demonstrated by the finding that Crry deficiency in utero leads to progressive embryonic lethality. ${ }^{44}$ Crry-/- embryos are surrounded by activated C3 fragments and PMN. Importantly, Crry-/- embryos are completely rescued from this $100 \%$ lethality and live pups are born at a normal Mendelian frequency when Crry $+/$ - parents are intercrossed with C3-/- mice to generate C3-/-, Crry-/- embryos. ${ }^{44}$ This outcome is genetic proof that Crry-/- embryos die in utero because of their inability to suppress complement activation and tissue damage mediated by $\mathrm{C} 3$. These findings underscore the need for a systematic evaluation of our hypothesis: that appropriate complement regulation is necessary to control 

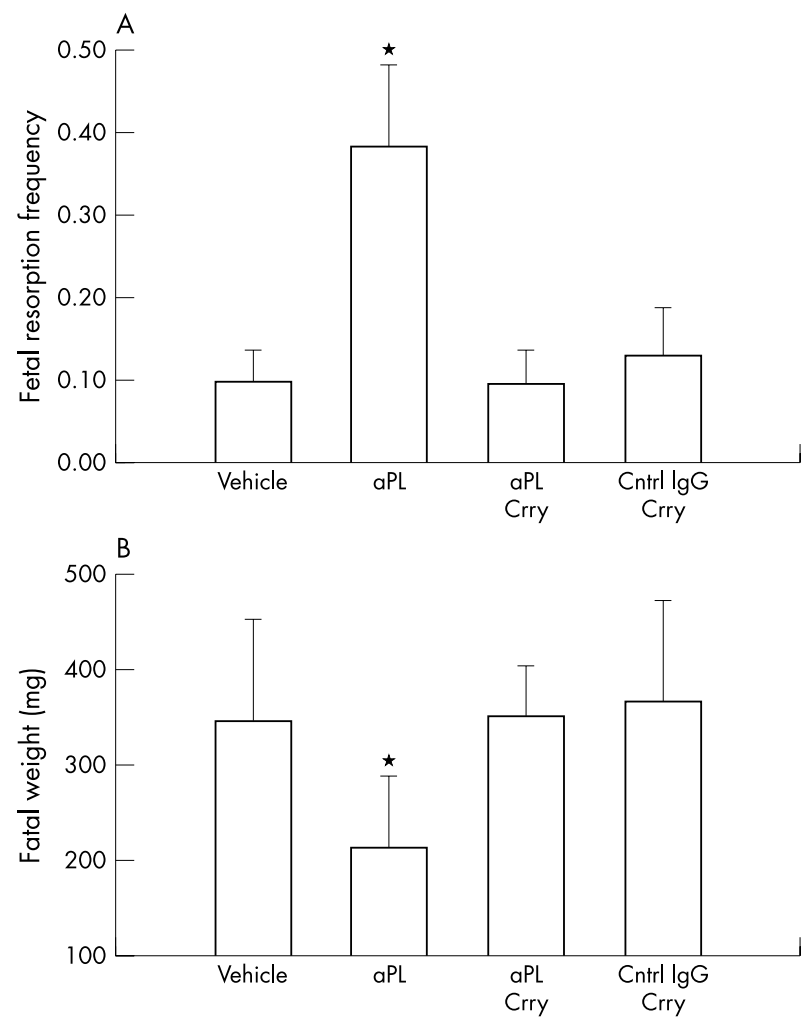

Figure 2 Inhibiton of $\mathrm{C} 3$ convertase ameliorates aPL-lgG induced pregnancy complications. Female BALB/c mice were treated ip with $\lg G(10 \mathrm{mg})$ from a patient with APS (aPL), normal human lgG (Cntrl $\operatorname{lgG}$ ) or saline (Vehicle) on days 8 and 12 of pregnancy. Some of the mice received an inhibitor of C3 convertase, Crry-lg (3 mg ip) every other day from days 8-12. Mice were killed on day 15 of pregnancy, uteri were dissected, fetuses were weighed, and frequency of fetal resorption calculated (number of

resorptions/number of fetuses + number of resorptions). There were six mice in each group. (A) Treatment with aPL-lgG caused an increase in fetal resorptions compared with vehicle or control human $\lg G\left({ }^{*} \mathrm{p}<0.05\right)$, which was prevented by Crry-lg ( ${ }^{*} \mathrm{aPL} v$ aPL + Crry-lg $p<0.05$ ). (B) aPL-lgG caused fetal growth retardation (*aPL $v$ Cntrl lgG $p<0.01$ ), which was also prevented by Crry-lg (*aPL $v$ aPL + Crry-lg p<0.01). Reproduced from the J Exp Med 2001;195:214 by copyright permission of The Rockefeller Press. maternal alloreactivity and placental inflammation in humans, and that a local increase in complement activation fragments is highly deleterious to the developing fetus.

\section{COMPLEMENT C3 ACTIVATION IS REQUIRED FOR APL ANTIBODY INDUCED FETAL LOSS AND THROMBOSIS}

To test the hypothesis that aPL antibodies activate complement in the placenta, leading to fetal injury, we used a murine model of APS in which pregnant mice are injected with human IgG containing aPL antibodies. We found that inhibition of the complement cascade in vivo, using the C3 convertase inhibitor Crry-Ig that blocks activation of $\mathrm{C} 3$ by both the classic and alternative pathways, prevents fetal loss and growth restriction (fig 2). Furthermore, mice deficient in complement $\mathrm{C} 3$ were resistant to fetal damage induced by aPL antibodies (fig 3). While antigenic epitopes recognised by aPL antibodies are important in the pathogenesis of APS, our data show that in vivo complement activation is required for aPL induced injury. That results from experiments with monoclonal human aPL antibodies were similar to results obtained with polyclonal aPL antibodies indicates that antibodies reactive with aPL, rather than xenoreactive antibodies which may be present in polyclonal human IgG, initiate complement activation and fetal damage in our model.

To discover if excessive complement activation occurs within the placenta in aPL treated mice, we conducted immunohistological analyses of decidua on day 8 of pregnancy, after the first treatment with aPL-Ig or control IgG. In preliminary experiments, we confirmed that human IgG was deposited in the decidua of mice treated with aPL-IgG or with aPL-IgG and Crry-Ig, whereas there was no evidence of IgG deposition in mice treated with control human IgG. In aPL treated mice, the decidua was abnormal morphologically, showing focal necrosis, apoptosis, and PMN infiltrates. In addition, there was extensive C3 deposition. Human IgG deposition and C3 activation were evident within 30 minutes after aPL treatment. In contrast, in mice treated with control human IgG only small amounts of C3 staining were detectable, mostly in the extraembryonic tissues; the decidua was not inflamed and had normal cellular elements. Treatment with Crry-Ig at the time of administration of aPL-IgG completely prevented inflammation and C3 deposition. Thus, using three distinct approaches, specific complement inhibitor (Crry-Ig), genetically deficient mice (C3-/-), and immunohistochemical evidence that absence of $\mathrm{C} 3$ deposition in Crry-Ig treated mice

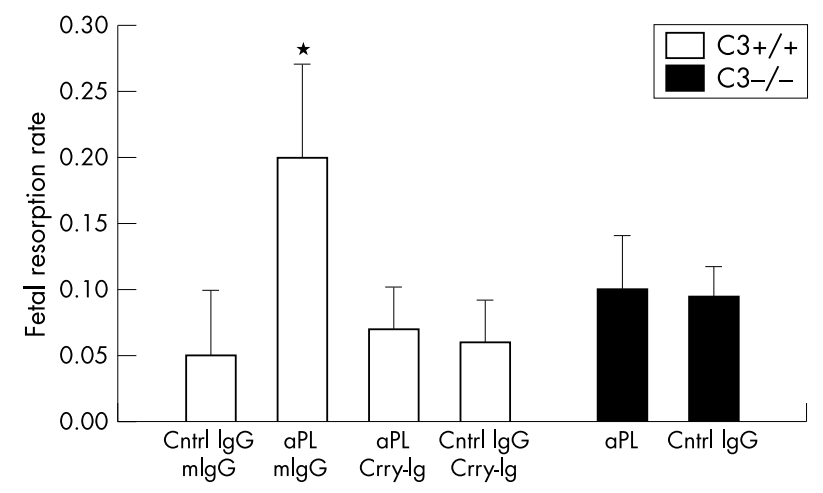

Figure 3 C3 deficient mice are protected from aPL antibody induced pregnancy complications. C3+/+ mice (B6/Sv129F1) were treated with

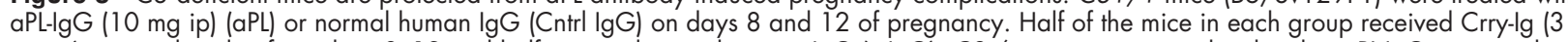
$\mathrm{mg}$ ip) every other day from days 8-12 and half received control murine $\lg \mathrm{G}(\mathrm{mlg})$. C3-\% mice were treated with either aPL-lgG or normal human $\lg G$. Pregnancy outcomes were assessed as described in the legend for fig 2. There were 10-14 mice in each experimental group. (A) Analysis of the four groups of $\mathrm{C} 3+/+$ mice shows that treatment with aPL-IgG caused an increase in frequency of fetal resorptions in this strain (*aPL + mlgG $v$ Cntrl lgG + mlgG p<0.01), while C3-/- were protected from aPL induced pregnancy loss (aPL $v$ Cntrl lgG p=NS). In the $\mathrm{C} 3+/+$ mice, Crry-lg prevented aPL induced fetal resorption ( ${ }^{*} \mathrm{aPL}+\mathrm{mlgG} v$ aPL + Crry-lg $\mathrm{p}<0.01$ ). (B) Similarly, aPL treatment caused a decrease in fetal weight in $C 3+/+$ mice ( $\left.{ }^{*} a P L+m \lg G \vee C n t r l ~ l g G+m \lg G p<0.01\right)$, which was absent in C3-/- mice, and this was ameliorated by Crry-lg (*aPL + mlgG v aPL + Crry-lg p<0.01). Reproduced from the J Exp Med 2001;195:216 by copyright permission of The Rockefeller Press. 


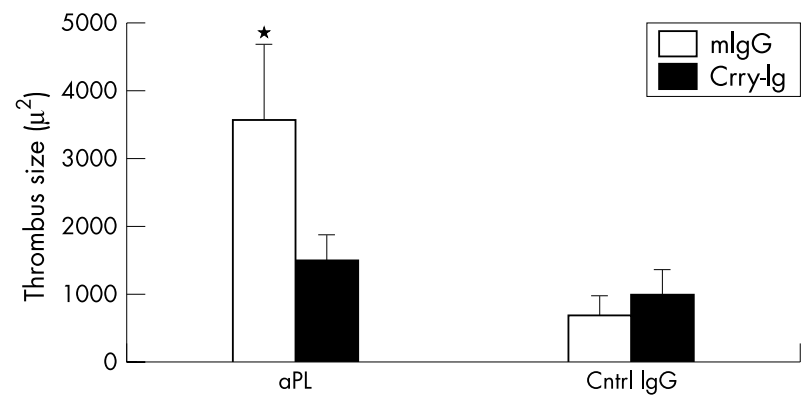

Figure $4 \mathrm{C} 3$ activation is required for aPL induced thrombophilia. (A) aPL-lgG induced thrombophilia is inhibited by Crry-lg. CD-1 mice were injected ip with affinity purified aPL-lgG (aPL) or normal human ( $\mathrm{Cntrl} \lg \mathrm{G}$ ) at 0 hours and 48 hours. Half the mice in each group received Crry-lg, and half the mice received control murine $\lg G$ (mlgG). At 72 hours after the first injection, surgically induced thrombus formation was measured as described in the text. There were 11-14 mice in each experimental group. Treatment with aPL-lgG caused an increase in thrombus size ( ${ }^{*} a P L+m l g G ~ v C$ ntrl $\lg G+\operatorname{mlg} G \quad p<0.05)$, while Crry-lg prevented aPL induced enhancement of thrombosis ( ${ }^{\mathrm{aPL}}+\mathrm{mlgG} v \mathrm{aPL}+$ Crry-lg $\mathrm{p}<0.05$ Cntrl lgG + Crry-lg $v$ aPL + Crry-lg, $p=N S)$. In a separate series of experiments, aPL did not significantly increase thrombosis in C3-/mice (aPL $v$ control lgG 1524 (825) um v 1083 (443), $p=N S$ ). There was no difference in the levels of human aPL activity between $\mathrm{C} 3+/+$ mice and C3-/- mice. Reproduced from the J Exp Med $2001 ; 195: 217$ by copyright permission of The Rockefeller Press.

correlates with improved outcomes, we demonstrated that complement activation is required for fetal loss and growth restriction in this murine model of APS.

To better understand the mechanism by which Crry-Ig protects against aPL induced fetal loss, we tested the hypothesis that complement inhibition blocks thrombosis generation. Using an in vivo microcirculation model in which aPL antibodies had been shown to enhance and accelerate thrombus formation in the presence of a vascular injury, we demonstrated that Crry-Ig prevents thrombophilia and that $\mathrm{C} 3-\mathrm{-}$ mice were resistant to aPL induced effects (fig 4).
Although it is not clear from our results which complement components or receptors are primarily responsible for fetal loss mediated by aPL antibodies, probable candidates include C3a and/or C5a or the C5b-9 MAC. C5a and the C5b-9 MAC have well described effects on platelets and endothelial cells. ${ }^{45} 46$ Blockade of $\mathrm{C} 5$ may be as effective as blockade of $\mathrm{C} 3$, perhaps because the anaphylatoxin $\mathrm{C} 3 \mathrm{a}$ is unable to recruit neutrophils (PMN) whereas C5a attracts PMN to inflammatory sites and activates them. ${ }^{47}$ Of note, histological evidence suggests that PMN are important effectors in our model of fetal loss. In addition, inhibition of the complement cascade focused at the level of $\mathrm{C} 5$ is attractive from a clinical standpoint because it blocks downstream effectors while preserving important complement derived immunoprotective functions, such as opsonisation and immune complex clearance.

In summary, our findings show that complement activation is a central mechanism contributing to aPL antibody induced thrombophilia, pregnancy loss, and fetal growth restriction. Although the cause of tissue injury in this disease is probably multifactoral, we have shown that complement activation is an absolute requirement for two of the most deleterious phenotypic outcomes in this condition and, therefore, that this pathway acts upstream of other important effector mechanisms.

\section{CONCLUSIONS}

Based on our findings, we proposed the following mechanism for the pathogenic effects of aPL antibodies (fig 5). Firstly, aPL antibodies are preferentially targeted to the placenta. Secondly, placental aPL antibodies promote platelet and endothelial cell activation and directly induce procoagulant activity through interaction with elements of the coagulation pathway. ${ }^{21} 2348-51$ This activity, however, does not seem to be sufficient to cause fetal loss or growth restriction as C3-/- mice are protected. Activation of the complement pathway amplifies these effects by the generation of further potent mediators of effector cell activation, including C3a, C5a, and C5-9 MAC, causing thrombosis, tissue hypoxia, and inflammation within the placenta, and ultimately leading to fetal injury. Depending on the extent of damage, either death in utero or fetal growth restriction ensues.

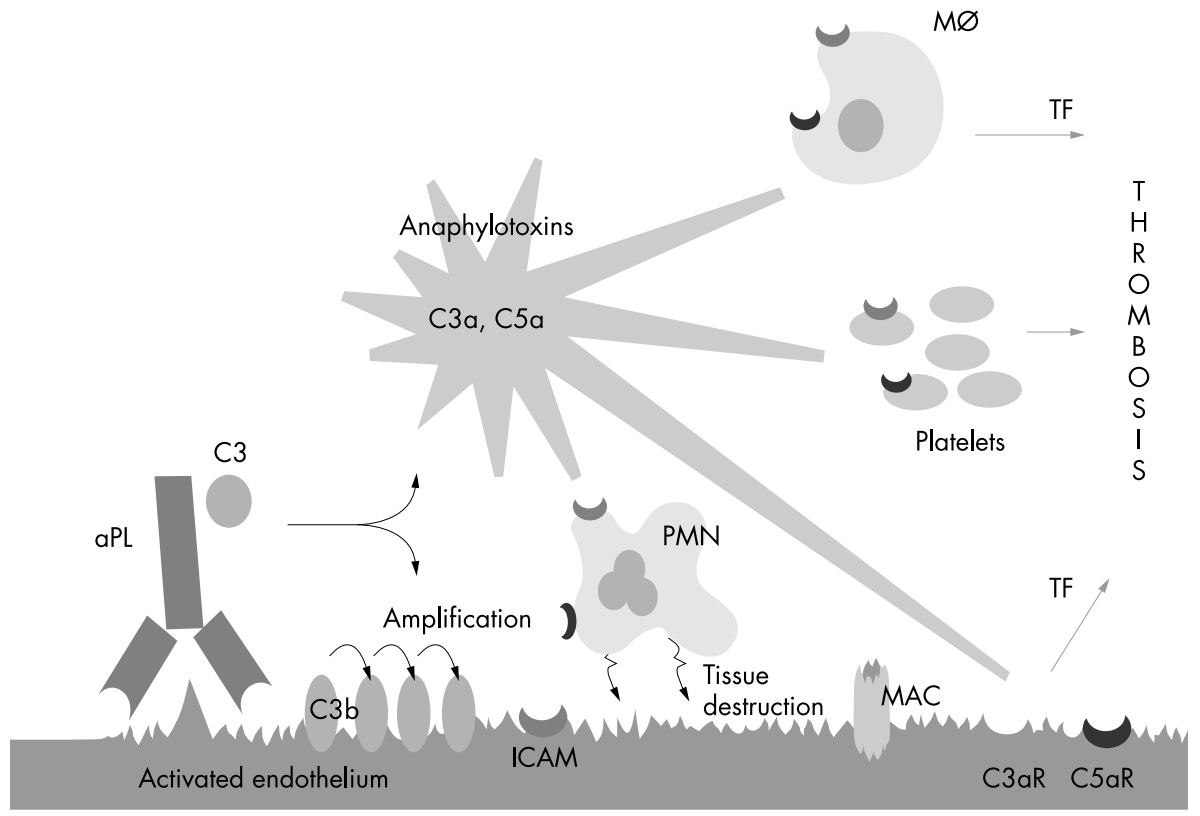

Figure 5 Proposed mechanism for the pathogenic effects of aPL antibodies on pregnancy outcome. aPL antibodies are preferentially targeted to the placenta where they may promote platelet and endothelial cell activation and directly induce procoagulant activity through interaction with elements of the coagulation pathway. This activity, however, does not seem to be sufficient to cause fetal loss or growth restriction; C3-/are protected. Activation of the complement pathway by aPL-lgG overwhelms the normally adequate inhibitory mechanisms and amplifies these effects by stimulating the generation of further potent mediators of effector cell activation, including C $3 a, C 5 a$, and the C5b-9 MAC. The addition of these complement activation products causes thrombosis, tissue hypoxia, and inflammation within the placenta, and ultimately leads to fetal injury. 
Identification of complement activation as a mechanism that is necessary for aPL induced tissue damage and definition of the complement components necessary to trigger such injury is likely to lead to a better understanding of the pathogenesis of vascular and tissue injury in SLE and to new and improved treatments. Our data generated in the murine model of APS, the availability of newer and more accurate tests of complement activation, and the recent development of effective and specific complement inhibitors argue persuasively that the role of complement in aPL associated pregnancy complications should be further examined. Indeed, our studies show that complement is a new target for treatment in patients with thrombotic and vascular complications of aPL syndrome.

\section{Authors' affiliations}

J E Salmon, G Girardi, Department of Medicine, Hospital for Special Surgery-Weill Medical College, Cornell University, New York, USA

V M Holers, Departments of Medicine and Immunology, University of

Colorado Health Sciences Center, Denver, USA

Correspondence to: Dr J E Salmon, Hospital for Special Surgery, 535 East 70th Street, New York, NY 10021, USA; salmonj@hss.edu

\section{REFERENCES}

1 Wilson WA, Gharavi AE, Koike T, Lockshin MD, Branch DW, Piette JC, et al. International consensus statement on preliminary classification criteria for definite antiphospholipid syndrome. Arthritis Rheum 1999; 42:1309-11.

2 Lockshin MD, Sammaritano LS, Schwartzman SS. Validation of the Sapporo Criteria for antiphospholipid antibody syndrome. Arthritis Rheum 2000;43:440-3

3 Kaleli K, Kaleli I, Aktan E, Turan C, Aksit F. Antiphospholipid antibodies in preeeclamptic women. Gynecol Obstet Invest 1998;45:81-4.

4 Kutteh WH. Antiphospholipid antibody-associated recurrent pregnancy loss: treatment with heparin and low-dose aspirin is superior to low-dose aspirin alone. Am J Obstet Gynecol 1996; 174:1584-9.

5 Rai R, Cohen H, Dave M, Regan L. Randomized controlled trial of aspirin and aspirin plus heparin in pregnant women with recurrent miscarriage associated with phospholipid antibodies. BM 1997;314:253-7.

6 Clifford K, Rai R, Watson H, Regan L. An informative protocol for the investigation of recurrent miscarriage: preliminary experience of 500 consecutive cases. Hum Reprod 1994;9:1328-32.

7 Pattison NS, Chamley LW, Birdsall M, Zanderigo AM, Liddell HS, McDougall J. Does aspirin have a role in improving pregnancy outcome for women with the antiphospholipid syndrome? A randomized controlled trial. Am J Obstet Gynecol 2000;183:1008-12.

8 Stephenson MD. Frequency of factors associated with habitual abortion in 197 couples. Fertil Steril 1996:66:24-9.

9 Yetman DL, Kutteh WH. Antiphospholipid antibody panels and recurrent pregnancy loss: prevalence of anticardiolipin antibodies compared with other antiphospholipid antibodies. Fertil Steril 1996;66:540-6.

10 Levine JS, Rauch J, Branch DW. Anti-phospholipid syndrome. N Engl J Med 2002;346:752-63.

11 Branch DW, Khamashta MA. Antiphospholipid syndrome: obstetric diagnosis, management, and controversies. Obstet Gynecol (in press).

12 Branch DW, Silver RM, Blackwell JL, Reading JC, Scott JR. Outcome of treated pregnancies in women with antiphospholipid syndrome: an update of the Utah experience Obstet Gynecol 1992:80:614-20.

13 Lima F, Khamashta MA, Buchanan NM, Kerslake S, Hunt BJ, Hughes GR. A study of sixty pregnancies in patients with the antiphospholipid syndrome. Clin Exp Rheumatol 1996;14:131-6.

14 Branch DW, Dudley DJ, Mitchell MD, Creighton KA, Abbott TM, Hammond $\mathrm{EH}$, et al. Immunoglobulin $\mathrm{G}$ fractions from patients with antiphospholipid antibodies cause fetal death in BALB/c mice: a model for autoimmune fetal loss. Am J Obstet Gynecol 1990;163:210-16

15 Piona A, La Rosa L, Tincani A, Faden D, Magro G, Grasso S, et al. Placental thrombosis and fetal loss after passive transfer of mouse lupus monoclonal or human polyclonal anti-cardiolipin antibodies in pregnant naïve BALB/c mice. Scand J Immunol 1995;41:427-32.

16 Blank M, Cohen J, Toder V, Shoenfeld Y. Induction of antiphospholipid syndrome in naive mice with mouse lupus monoclonal and human polyclonal antibodies. Proc Natl Acad Sci USA 1991;88:3069-73.

17 Ikematsu W, Luan FL, La Rosa L, Beltrami B, Nicoletti F, Buyon JP, et al. Human anticardiolipin monoclonal autoantibodies cause placental necrosis and fetal loss in BALB/c mice. Arthritis Rheum 1998;41:1026-39.

18 Di Simone N, Meroni P, Del Papa N, Raschi E, Caliandro D, De Carolis CS, et al. Antiphospholipid antibodies affect trophoblast gonadotropin secretion and invasiveness by binding directly and through adhered B2-glycoprotein 1. Arthritis Rheum 2000;43:140-50.

19 Out HJ, Kooijman CD, Bruinse HW, Derksen RH. Histopathological findings in placentae from patients with intra-uterine fetal death and anti-phospholipid antibodies. Eur J Obstet Gynecol Reprod Biol $1991 ; 41: 179-86$.
20 Magid MS, Kaplan C, Sammaritano LR, Peterson M, Druzin ML, Lockshin $M D$. Placental pathology in systemic lupus erythematosus: a prospective study. Am J Obstet Gynecol 1998;179:226-34

21 Simantov R, LaSala J, Lo SK, Gharavi AE, Sammaritano LR, Salmon JE, et al. Activation of cultured vascular endothelium by antiphospholipid antibodies. J Clin Invest 1995:96:2211-19.

22 Papa ND, Raschi E, Moroni G, Panzeri P, Borghi MO, Ponticelli C, et al. Anti-endothelial cell lgG fractions from systemic lupus erythematosus patients bind to human endothelial cells and induce a pro-adhesive and a pro-inflammatory phenotype in vitro. Lupus 1999;8:423-9.

23 Pierangeli SS, Colden-Stanfield M, Liu X, Barker JH, Anderson GL, Harris EN. Antiphospholipid antibodies from antiphospholipid syndrome patients activate endothelial cells in vitro and in vivo. Circulation 1999;99: 1997-2002.

24 Holers VM. Complement, principles and practices of clinical immunology. In: Rich R, ed. St Louis, MO: Mosby, 1995:363.

25 Holers VM, Girardi G, Mo L, Guthridge JM, Molina H, Pierangeli SS, et al. Complement $\mathrm{C} 3$ activation is required for anti-phospholipid antibody-induced fetal loss. J Exp Med 2002;195:21 1-20.

26 Schmidt BZ, Colten HR. Complement: a critical test of its biological importance. Immunol Rev 2000;178:166-76.

27 Abbas AK, Lichtman AH, Pober JS. Effector mechanisms of humoral immunity. In: Cellular and molecular immunology. 4th edn. Philadelphia, PA: WB Saunders, 2000:316-34.

28 Fearon DT, Locksley RM. The instructive role of innate immunity in the acquired immune response. Science 1996:272:50-4.

29 Wetsel RA. Structure, function and cellular expression of complement anaphylatoxin receptors. Curr Opin Immunol 1995;7:48-53.

30 Brown EJ. Complement receptors and phagocytosis. Curr Opin Immunol 1991;3:76-82.

31 Gerard NP, Gerard C. The chemotactic receptor for human C5a anaphylatoxin. Nature 1991;349:614-17.

32 Wetsel RA. Structure, function and cellular expression of complement anaphylatoxin receptors. Curr Opin Immunol 1995;7:48-53.

33 Foreman KE, Vaporciyan AA, Bonish BK, Jones ML, Johnson KJ, Glovsky $\mathrm{MM}$, et al. C5a-induced expression of P-selectin in endothelial cells. J Clin Invest 1994;94:1 147-55.

34 Shin ML, Rus HG, Nicolescu Fl. Membrane attack by complement: assembly and biology of terminal complement complexes. Biomembranes 1996;4:123-49.

35 Morgan BP, Meri S. Membrane proteins that protect against complement lysis. Springer Semin Immunopathol 1994;15:369-96.

36 Carroll MC. The role of complement and complement receptors in the induction and regulation of immunity. Annu Rev Immunol 1998; 16:545-68.

37 Holmes $\mathbf{C H}$, Simpson KL. Complement and pregnancy: new insights into the immunobiology of the fetomaternal relationship. Baillieres Clin Obste Gynaecol 1992;6:439-59.

38 Weir PE. Immunofluorescent studies of the uteroplacental arteries in normal pregnancy. Br J Obstet Gynaecol 1981;88:301-7.

39 Wells M, Bennett J, Bulmer JN, Jackson P, Holgate CS. Complement component deposition in uteroplacental (spiral) arteries in normal human pregnancy. J Reprod Immunol 1987; 12:125-35

40 Cunningham DS, Tichenor JR. Decay-accelerating factor protects human trophoblast from complement-mediated attack. Clin Immunol Immunopathol 1995:74:156-61

41 Tedesco F, Narchi G, Radillo O, Meri S, Ferrone S, Betterle C. Susceptibility of human trophoblast to killing by human complement and the role of the complement regulatory proteins. J Immunol 1993; 151:1562-70.

42 Liszewski MK, Farries TC, Lublin DM, Rooney IA, Atkinson JP. Control of the complement system. Adv Immunol 1996;61:201-83.

43 Rehrig S, Fleming SD, Anderson J, Guthridge JM, Rakstang J, McQueen $C E$, et al. Complement inhibitor, complement receptor 1-related gene/protein $y$-lg attenuates intestinal damage after the onset of mesenteric ischemia/reperfusion injury in mice. J Immunol 2001;167:5921-7.

44 Xu C, Mao D, Holers VM, Palanca B, Cheng A, Molina H. A critical role for the murine complement regulator Crry in fetomaternal tolerance. Science 2000;287:498-501.

45 Imrie HJ, McGonigle TP, Liu DT, Jones DR. Regulation of erythrocyte complement receptor 1 (CR1) and decay accelerating factor during normal pregnancy. J Reprod Immunol 1996;31:221-7.

46 Chaouat G, Menu E, Clark DA, Minkowsky M, Dy M, Wegmann TG Control of fetal survival in CBAxDBA/2 mice by lymphokine therapy. J Reprod Fertil 1990;89:447-58.

47 Daffern PJ, Pfeifer PH, Ember JA, Hugli TE. C3a is a chemotaxin for human eosinophils but not for neutrophils. I. C3a stimulation of neutrophils is secondary to eosinophil activation. J Exp Med 1995:181:2119-27.

48 Donohoe S, Kingdom JC, Mackie IJ. Affinity purified human antiphospholipid antibodies bind normal term placenta. Lupus 1999;8:525-31

49 Del Papa N, Guidali L, Sala A, Buccellati C, Khamashta MA, Ichikawa $\mathrm{K}$, et al. Endothelial cells as target for antiphospholipid antibodies. Human polyclonal and monoclonal anti-beta 2-glycoprotein I antibodies react in vitro with endothelial cells through adherent beta 2-glycoprotein and induce endothelial activation. Arthritis Rheum 1997;40:551-61

50 Esmon NL, Safa O, Smirnov MD, Esmon CT. Antiphospholipid antibodies and the protein $C$ pathway. J Autoimmun 2000;15:221-5.

51 Devine DV. The effects of complement activation on platelets. Curr Top Microbiol Immunol 1992;178:101-13. 